\title{
Sex, Violence and Crime: Foucault and the 'Man' Question
}

\section{Adrian Howe. Routledge-Cavendish, Abingdon, Oxfordshire UK. 2008, ISBN 978-1-904385-10-3, 238 pages, US\$59.95 (Paperback)}

\section{Monica Williams}

Received: 14 August 2009 / Accepted: 18 August 2009 /

Published online: 2 September 2009

(C) The Author(s) 2009. This article is published with open access at Springerlink.com

In Sex, Violence and Crime, Adrian Howe uses discourse analysis to explore the "Man' question": accounting for men's role in violence against women. As a Foucauldian scholar, she aims to reveal how power and knowledge intersect to create truths that contribute to the consistent invisibility of men as perpetrators of violence against women. The book's organization reflects its origins in an undergraduate lecture series, with each chapter focused on a different type of discourse, including women's magazines, mainstream and critical criminological work, a case study, feminist movement history, and recent British policy. As a result, Sex, Violence and Crime reads like a series of compelling essays revolving around the common theme of how mainstream texts "erase" the men who perpetrate violence against women, thereby letting men off the hook while perpetuating victim-blaming.

At the outset, Howe introduces the reader to her love for Foucauldian theory and methods. She describes Sex, Violence and Crime as an "homage to Foucault", in part because she aims to rescue discourse analysis as a viable method of research. Thus, she sets off in Chap. 1 to show how representations of sex in mainstream women's magazines perpetuate sexuality based on heterosexual ideologies. The magazine articles she examines imply that women should focus on pleasing men rather than actively satisfying their own desires. In line with Foucault, she argues that these discursive representations construct sexuality as a site of power. In Chap. 2, Howe aims the discursive analytic technique at mainstream criminology, arguing that these studies of violence overlook, and sometimes inadvertently excuse, men's role in violence against women. Among her various critiques, she emphasizes the limits of aggregate data, the fallacy of focusing on women's violence, the dangers of sympathetic accounts of serial killers' violence, and the attribution of sex killers' motives to bad mothers.

In the next two chapters, Howe takes on the work of theorists ostensibly well-positioned to challenge mainstream criminology's neglect of men's role in violence against women. In

M. Williams $(\bowtie)$

Department of Sociology, University of California, Davis, 1 Shields Avenue, Davis, CA 95616, USA

e-mail: mwilliams@ucdavis.edu 
Chap. 3, she discursively analyzes Foucault's interpretation of the case of Pierre Rivière, a French peasant who, while awaiting trial for killing his mother, sister, and brother, wrote a memoir about the murder. Foucault heralds Rivière's memoir as a text that denies interpretation while simultaneously interpreting the murders as an act of peasant resistance. Howe draws heavily on Julie Marcus' critique to show that Foucault became so entrenched in the traditional masculinist reading of violence that he failed to question the role of gender in Rivière's violent acts. Likewise, Howe argues in Chap. 4 that critical criminologists, despite their focus on the relationship between sex, violence, and crime, have missed an opportunity to explore the role of men as key agents of violence against women. She also finds fault with masculinity studies because they divert attention from women's lived experience of men's violence against them. By the end of these two chapters, Howe has shown how hegemonic discourses about violence against women affect even those best situated to critique masculinist accounts of that violence.

Chapters 5 and 6 mark a distinct departure from the first four. Howe's discussions about the diversification of feminist movements and the emergence of recent British domestic violence policies provide interesting accounts of what happens when activists foreground men's violence against women. Yet, neither chapter clearly focuses on the "Man question" and Howe does not discursively analyze the place of men in campaigns to eliminate violence against women. Moreover, she overlooks the work on men that feminists have contributed to academic discourse. While these two chapters illustrate the obstacles to naming men's violence in public policy arenas, the book would have been strengthened had Howe continued to use discourse analysis to deconstruct feminist activism. Without this, she implicitly relies on the notion that feminist answers to the "Man question" will likely be the most satisfactory. This claim contradicts her assertion in earlier chapters that even those well-positioned to examine men as agents of violence against women fail to do so.

Howe concludes with a short epilogue in which she asserts that the main goal of the book is to shift perceptions about violence against women. In this, she succeeds. Each chapter contributes to the overall project of making the reader contemplate the implied, but never recognized, active subject when discussing violence against women. Yet, social scientists may be troubled by her unsystematic data collection. For example, Chap. 2 provides a useful overview of criminological theory regarding violence, but Howe draws on materials selected randomly from journals and textbooks. A more systematic reading of criminological literature that involved assessing the relative importance of each of these texts to mainstream criminology would have strengthened her argument. The same problem besets the chapters on magazines and critical criminology.

Throughout the book, Howe also achieves a secondary aim of undermining myths about feminism, the most common being that of a singular ("radical") feminist viewpoint. She constantly points out that she is not a "radical" feminist. Instead, she does a good job of illustrating how "erasing" men from accounts of violence against women stems from the power of discourse, rather than a conspiracy to make men's role in violence invisible. By pointing out diverse feminisms, and summarizing in Chap. 5 the variety of feminist viewpoints, Howe undermines mainstream theorists who refuse to explore men's violence because they reject "a feminist" interpretation of violence against women.

Overall, Sex, Violence and Crime advances thought-provoking arguments that open the door for further investigation into men's violence against women. Advanced undergraduate and graduate students will appreciate the overview and critique of prominent criminological and feminist theorists, and activists could learn from the final chapter's account of the problems besetting those working to eliminate men's violence against women. Criminologists may find the overview of literature and theories tedious and elementary at times, but 
can still benefit from Adrian Howe's unique interpretation of these texts. In short, Sex, Violence and Crime provides a new perspective on violence against women that will surely invigorate theories about the sexed nature of violent crime, and debates about how to solve this ubiquitous problem.

Open Access This article is distributed under the terms of the Creative Commons Attribution Noncommercial License which permits any noncommercial use, distribution, and reproduction in any medium, provided the original author(s) and source are credited. 